\title{
Development of multivariate calibration method for simultaneous determination of nickel, lead and zinc in tap water
}

- Huynh Minh Chau

- Ly Du Thu

- Pham Thai Thach

- Pham Thi Bao Tran

- Duong Khanh Minh

- Nguyen Anh Mai

University of Science, VNU-HCM

(Received on December $12^{\text {th }} 2014$, accepted on August $12^{\text {th }} 2015$ )

\section{ABSTRACT}

Conventional spectrophotometric methods for simultaneous determination of nickel, lead and zinc in forms of complexes with a reagent is not feasible due to the overlap of their absorption spectra. $A$ multivariate calibration method was used to overcome this problem. In this study, the calibration model was constructed based on absorption spectra of 30 mixture standards in the range from 490 to $600 \mathrm{~nm}$. Factors influencing experimental results such as

Key words: Partial least squares, lead, nickel, zinc, spectrophotometry, multivariate calibration.

\section{INTRODUCTION}

Nickel, lead and zinc co-exist in many samples. Several techniques such as XFS [1], polarography [2], AAS [3], ICP-OES [4] were used to determine these metal ions. Among these techniques, spectrophotometry was commonly used in thanks to its low instrumental investment and the ease of performance. However, direct determination of the metal ions without prior separation is impossible due to the spectral overlap. Real samples having complicated amount of reagents, $\mathrm{pH}$, and color development time were optimized. The standard calibration ranges for determination of nickel, lead and zinc were found at 0.5-5 ppm. The method was applied for determination of these ions in tap water samples at ppm level, with recoveries (and RSD) of nickel, lead and zinc were $103.3 \%$ (3.0\%), $74.9 \%(11.5 \%)$ and $104.6 \%$ (4.6\%), respectively.

components usually have overlapped absorption spectra which decreases accuracy. This research depicted a method for simultaneous determination of nickel, lead and zinc by combining spectrophotometry with multivariate calibration technique to increase the speed and accuracy of the analysis. Complexes of these ions with xylenol orange (XO) in synthetic and tap water samples were analyzed by spectrophotometry without any prior treatment. 
Achieved data was treated by partial least square method (PLS) to build a correlation vector to predict concentration of each component in the samples from their spectral signals. The data were in the form of matrices. Rows of $\mathrm{X}$ and $\mathrm{Y}$ matrices were absorbance at every wavelength of a standard mixture and the corresponding concentrations of the ions, respectively [5]. These two matrices can be described as equations (1) and (2).

$$
X=T \cdot P^{t}+E(1) \quad Y=U \cdot Q^{t}+F
$$

where T, $\mathrm{P}$, and $\mathrm{E}$ are $\mathrm{X}$-scores, $\mathrm{X}$-loadings, and X-residuals, respectively. And U, Q, and F are the same coefficients for $\mathrm{Y}$ matrix. $\mathrm{T}$ and $\mathrm{U}$ were correlated as in equation (3) $\left[u_{f}=b_{f} t_{f}\right]$ with bf is the regression coefficient for the $f$ latent variable. After replacing uf in $\mathrm{Y}$, the new equation (4) is $Y=T B Q^{t}+F$. To calculate the concentration of each components of new samples, new scores $\mathrm{T}^{*}$ replace $\mathrm{T}$ in the equation (4) as followed:

$$
Y_{\text {new }}=T^{*} B Q^{t}
$$

The more detailed calibration set was built (or more standard mixtures were used), the higher its predictive ability would have.

\section{EXPERIMENTAL}

\section{Materials and equipment}

Lead, nickel and zinc standard mixture solutions were prepared from their individual stock solutions which were purchased from Merck (Germany). 1000 ppm stock solutions of these metals were prepared in $0.5 \%$ nitric acid and stored at $\sim 7{ }^{\circ} \mathrm{C}$; from which working solutions were prepared daily with distilled water. Nitric acid, acetic acid, sodium acetate, and xylenol orange (XO) from Guangdong Guanghua Co. (China) were of analytical grade.

A Shimadzu AA-6650 Atomic Absorption Spectrophotometer equipped with an Auto Sampler ASC-6100. Standard solutions were used to confirm the content of metals in samples.

A Shimadzu UV-1800 UV-VIS Spectrophotometer controlled by UV Probe software and a $1.00 \mathrm{~cm}$ glass cells was used in this study. $\mathrm{pH}$ of buffers were adjusted by Schott Instrument Lab850 $\mathrm{pH}$ meter and the data were treated by SIMCA P-11 software (Umetrics, Sweden).

\section{Spectrophotometric condition optimization}

Prior to multicalibration study the conditions for complex formation were investigated. Times for full color development, $\mathrm{pH}$ and concentration ratio of metal ions to $\mathrm{XO}$ were optimized. Complexes of three analytes and $\mathrm{XO}$ were used for all investigations of $\mathrm{pH}$, reaction time, and ration of M:XO.

Spectra of metal ion (M)-XO complexes were recorded from 400-700 $\mathrm{nm}$ against a reagent blank with an interval of $1 \mathrm{~nm}$. Individual $\mathrm{M}-\mathrm{XO}$ complex solutions were prepared in $60 \mathrm{mM}$ acetate buffer and the concentration ratio of $\mathrm{M}: \mathrm{XO}$ was of 1:2.

Optimal $\mathrm{pH}$, reaction time, and concentration ratio of $\mathrm{M}: \mathrm{XO}$ were searched in ranges of 4.0-6.0, 5-85 min, and 1:2-1:20, respectively by measuring absorbance of M-XO solutions at $582 \mathrm{~nm}$. 
Preparation of metal ion mixtures for calibration and validation

Table 1. Concentration of metal ions in standard mixtures used as the calibration set

\begin{tabular}{|c|c|c|c|c|c|c|c|c|c|c|c|}
\hline \multirow[b]{2}{*}{ Code } & \multicolumn{3}{|c|}{ Concentration (ppm) } & \multirow[b]{2}{*}{ Code } & \multicolumn{3}{|c|}{ Concentration (ppm) } & \multirow[b]{2}{*}{ Code } & \multicolumn{3}{|c|}{ Concentration (ppm) } \\
\hline & $\mathbf{N i}$ & $\mathbf{P b}$ & $\mathbf{Z n}$ & & $\mathbf{N i}$ & $\mathbf{P b}$ & $\mathbf{Z n}$ & & $\mathbf{N i}$ & $\mathbf{P b}$ & $\mathbf{Z n}$ \\
\hline 111 & 0.498 & 0.513 & 0.509 & 212 & 2.740 & 0.513 & 2.801 & 313 & 4.982 & 0.513 & 5.093 \\
\hline 211 & 2.740 & 0.513 & 0.509 & 312 & 4.982 & 0.513 & 2.801 & 123 & 0.498 & 2.822 & 5.093 \\
\hline 121 & 0.498 & 2.822 & 0.509 & 222 & 2.824 & 2.877 & 2.784 & 323 & 4.982 & 2.822 & 5.093 \\
\hline 221 & 2.740 & 2.822 & 0.509 & 322 & 4.982 & 2.822 & 2.801 & 133 & 0.498 & 5.131 & 5.093 \\
\hline 321 & 4.982 & 2.822 & 0.509 & 132 & 0.498 & 5.131 & 2.801 & 233 & 2.740 & 5.131 & 5.093 \\
\hline 131 & 0.498 & 5.131 & 0.509 & 232 & 2.740 & 5.131 & 2.801 & 333 & 4.982 & 5.131 & 5.093 \\
\hline 112 & 0.498 & 0.513 & 2.801 & 213 & 2.740 & 0.513 & 5.093 & 222 & 2.845 & 2.925 & 2.908 \\
\hline
\end{tabular}

A calibration set consisting of 30 standard mixtures were prepared varying the metal concentrations from 0.5-5.0 ppm. We encoded the lowest concentration in each component as 1 , the middle as 2 and the highest as 3 , in the order of $\mathrm{Ni}^{2+}, \mathrm{Pb}^{2+}$ and $\mathrm{Zn}^{2+}$ (Table 1). In order to validate the developed method, 9 samples of these ions were prepared in distilled water (Table 2).

\section{Atomic Absorption Spectrometry (AAS) confirmation}

The concentrations of metal ions of the mixtures were confirmed by AAS. The absorbance was measured at 232, 217 and 213.9 $\mathrm{nm}$ for nickel, lead and zinc, respectively.

\section{RESULTS AND DISCUSSION}

\section{Spectrophotometric analysis conditions}

Spectra of the M-XO complexes show that maximal absorptions were observed at 582, 570 and $561 \mathrm{~nm}$ for $\mathrm{Ni}-\mathrm{XO}, \mathrm{Pb}-\mathrm{XO}$ and $\mathrm{Zn}-\mathrm{XO}$, respectively (Fig. 2-I). In addition, $\mathrm{Pb}-\mathrm{XO}$ complex had the lowest sensitivity while $\mathrm{Ni}-\mathrm{XO}$ had the highest one.

In the investigation of $\mathrm{pH}$, reaction time and concentration ratio, measurements of the mixture were carried out at $582 \mathrm{~nm}$. It was found that $\mathrm{pH}$ of 5.5, reaction time of $55 \mathrm{~min}$ and the concentration ratio $\mathrm{M}: \mathrm{XO}=1: 2$ were the best conditions regarding sensitivity and repeatability. Unfortunately, it is impossible to have this ratio constant for samples with unknown $\mathrm{M}^{2+}$ levels. Therefore from now on a fixed amount of XO was used for complexation and this resulted in the ratio varied from 1:2-1:20 depending on the $\mathrm{M}^{2+}$ level. 


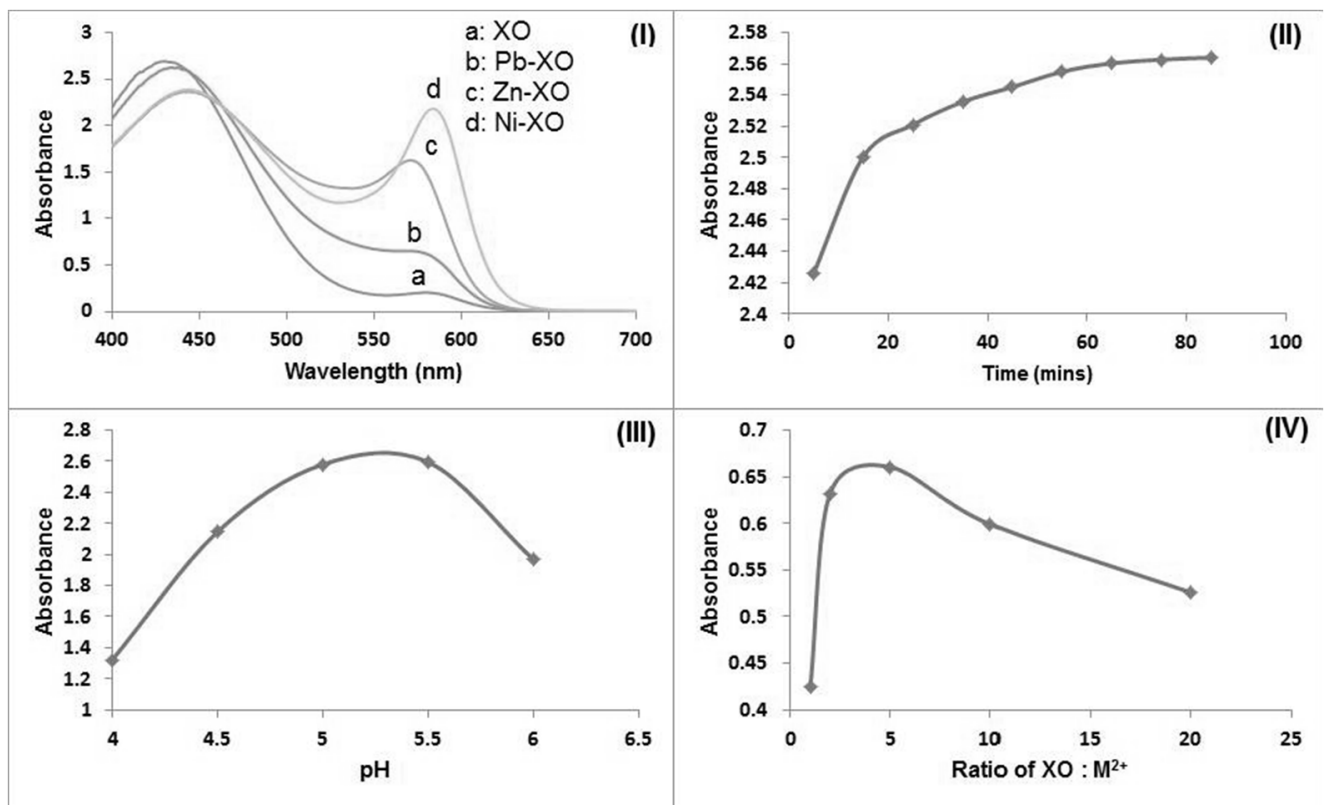

Figure 2. Optimization condition results of spectrophotometric procedure

\section{Calibration model}

Partial least square (PLS) was used to treat the spectrophotometric data. It should be noted that only spectra in the range from $490-600 \mathrm{~nm}$ were used for this work since $\mathrm{XO}$ absorbed strongly at lower wavelength and very low signals of M-XO at wavelength higher than $600 \mathrm{~nm}$.

The score plot offered by PLS indicated the distribution of the standard mixtures (Fig. 3). It is obvious that $\mathrm{Ni}^{2+}$ had the strongest influence on the distribution and samples with increasing level of $\mathrm{Ni}^{2+}$ were distributed along $\mathrm{t}_{1}$ from left to right, while samples with increasing $\mathrm{Zn}^{2+}$ levels were separated by $t_{2}$ from bottom to top. The situation of $\mathrm{Pb}^{2+}$ was the same as $\mathrm{Zn}^{2+}$ but to a lesser extent. In other words, the influence order of the ions on the spectra of their mixtures decreased from $\mathrm{Ni}^{2+}$, $\mathrm{Zn}^{2+}$ to $\mathrm{Pb}^{2+}$. A more careful look on the score plot one can easily found that at higher concentration of $\mathrm{Ni}^{2+}$ and $\mathrm{Zn}^{2+}$, the much weaker influence of $\mathrm{Pb}^{2+}$ level in differentiating the samples as emphasized by open circles in the score plot, especially at high level of nickel and zinc. It illustrated that the stronger absorption intensities were, the more significant model effect of analytes was. These observations could lead to higher errors of predicted $\mathrm{Pb}^{2+}$ level by the model.

The model fitness, $\mathrm{R}^{2}$, and prediction ability, $\mathrm{Q}^{2}$, were of 0.979 and 0.958 , respectively showing that in general the model was of good quality and can be used to predict the ion levels [6].

\section{Trang 148}




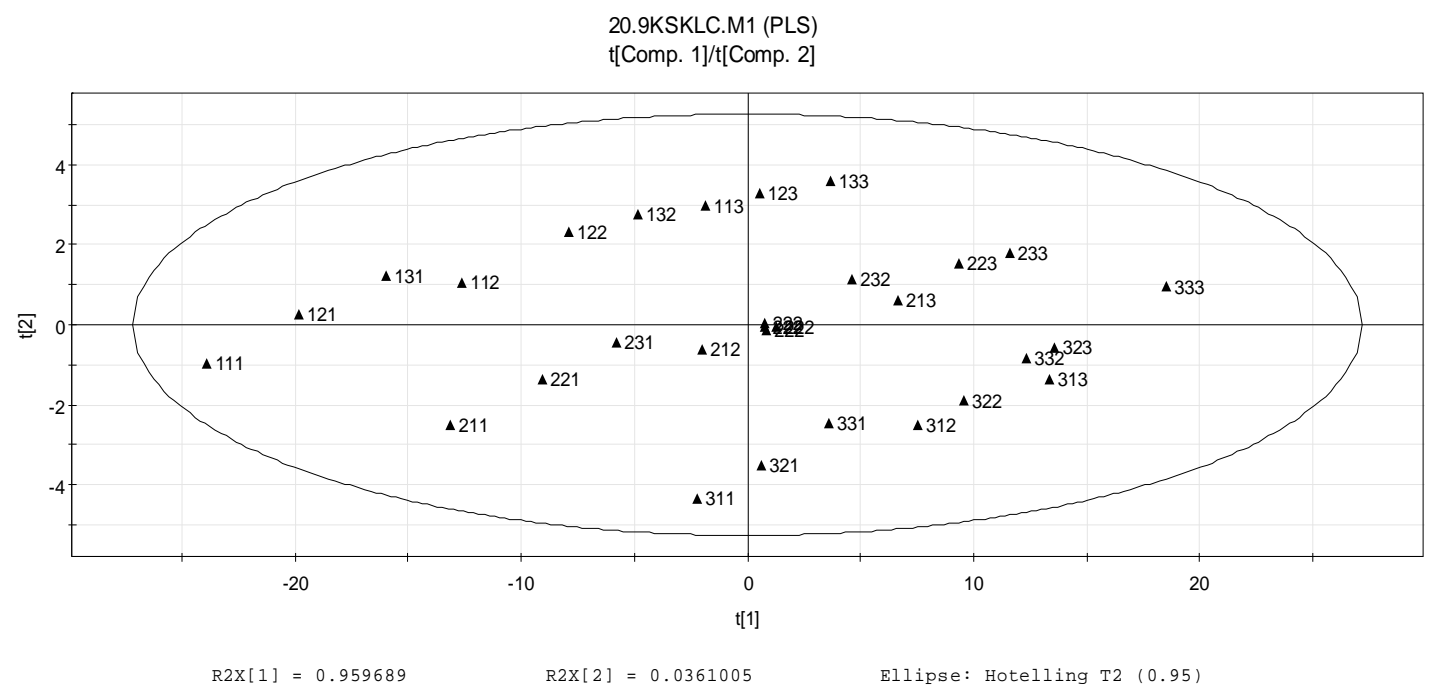

Figure 3. The score plot of 30 calibration samples

(Denoted levels of $\mathrm{Ni}^{2+}, \mathrm{Pb}^{2+}, \mathrm{Zn}^{2+}$ in mixtures as "xyz", with $\mathrm{x}, \mathrm{y}, \mathrm{z}$ values were 1, 2, 3 correspond to the lowest, medium and highest level)

\section{Application to water samples prepared in} pure water and in tap water

The predictive ability of model was tested using 9 samples prepared in distilled water (Table 2). It illustrated that the proposed procedure was successfully applied for the assay of nickel, lead and zinc simultaneously in synthetic samples at ppm level. The average RSDs were acceptable, 3.0, 11.5, and $4.6 \%$ for nickel, lead and zinc, respectively. The satisfactory recoveries were achieved with $\mathrm{Ni}^{2+}$ and $\mathrm{Zn}^{2+}$. However, low level of $\mathrm{Pb}^{2+}$ in synthetic samples still had high errors and uncertainty due to the low sensitivity of its complex in comparison to the other two ions.

Table 2. The recoveries and RSDs validation samples

\begin{tabular}{|c|c|c|c|c|c|c|c|c|c|c|c|c|}
\hline \multirow{2}{*}{ Sample } & \multicolumn{3}{|c|}{ Added* } & \multicolumn{3}{|c|}{ Found** } & \multicolumn{3}{|c|}{ RSD $(\%)$} & \multicolumn{3}{|c|}{ Recovery (\%) } \\
\hline & $\mathbf{N i}$ & $\mathbf{P b}$ & $\mathbf{Z n}$ & $\mathbf{N i}$ & $\mathbf{P b}$ & $\mathbf{Z n}$ & $\mathbf{N i}$ & $\mathbf{P b}$ & $\mathbf{Z n}$ & $\mathbf{N i}$ & $\mathbf{P b}$ & $\mathbf{Z n}$ \\
\hline SS $1^{*}$ & 1.022 & 1.038 & 1.018 & 0.970 & 0.390 & 1.104 & 7.4 & 20.8 & 5.8 & 94.9 & 37.6 & 108.5 \\
\hline SS 2 & 2.601 & 1.054 & 1.018 & 2.613 & 0.792 & 1.025 & 1.5 & 11.2 & 7.3 & 100.5 & 75.1 & 100.7 \\
\hline SS 3 & 4.093 & 1.124 & 1.527 & 4.372 & 0.837 & 1.681 & 1.4 & 16.2 & 5.4 & 106.8 & 74.4 & 110.1 \\
\hline SS 4 & 1.009 & 2.512 & 4.072 & 1.124 & 1.238 & 4.455 & 8.3 & 6.9 & 1.3 & 111.4 & 49.3 & 109.4 \\
\hline SS 5 & 2.540 & 2.528 & 4.072 & 2.600 & 1.906 & 4.276 & 0.8 & 7.2 & 1.6 & 102.4 & 75.4 & 105.0 \\
\hline SS 6 & 4.014 & 3.061 & 5.090 & 4.134 & 2.508 & 5.182 & 1.0 & 19.7 & 4.5 & 103.0 & 82.0 & 101.8 \\
\hline SS 7 & 1.564 & 3.975 & 2.545 & 1.556 & 3.871 & 2.675 & 3.0 & 4.9 & 4.1 & 99.5 & 97.4 & 105.1 \\
\hline SS 8 & 3.047 & 4.024 & 2.545 & 3.169 & 3.732 & 2.694 & 2.5 & 9.9 & 6.0 & 104.0 & 92.7 & 105.9 \\
\hline SS 9 & 5.019 & 4.982 & 3.054 & 5.403 & 4.500 & 2.910 & 0.6 & 7.0 & 5.7 & 107.7 & 90.3 & 95.3 \\
\hline
\end{tabular}




\section{CONCLUSIONS}

The method for simultaneous determination of nickel, lead and zinc ions based on their complexes with xylenol orange was developed. By using spectrophotometric method combined partial least square as a multivariate calibration technique, it was possible to obtain a model from absorbance signals. Absorption spectra in the 490 to $600 \mathrm{~nm}$ range of 30 different standards of which concentrations found from 0.5 to $5 \mathrm{ppm}$ were used to create a model. The method was applied for determination of nickel, lead and zinc ions in synthetic samples without carrying out costly and time consuming for sample treatment. However the requirement of equal sensitivity for all components is the limitation of the method.

\section{Phát triển phương pháp đường chuẩn đa biến ứng dụng xác định đồng thời niken, chì và kẽm trong nước sinh hoạt}

- Huỳnh Minh Châu

- Lý Dự Thư

- Phạm Thái Thạch

- Phạm Thị Bảo Trân

- Dương Khánh Minh

- Nguyễn Ánh Mai

- Trường Đại học Khoa học Tự nhiên, ĐHQG-HCM

\section{TÓM TÁT}

Phương pháp trắc quang xác định đồng thời các kim loại độc hại trong nước như niken, chì và kẽm thường gặp nhiều khó khăn do sự chồng chập phổ của chúng. Phương pháp đường chuẩn đa biến dựa trên phương pháp bình phương tối thiểu từng phần được sử dụng để khắc phục. Trong nghiên cứu này, mô hình chuẩn được xây dựng dựa trên phổ hấp thu trong khoảng bước sóng từ 490 đến các yếu tố ảnh hưởng lên kết quả phân tích như lượng thuốc thử, $p H$ và thời gian cũng được tối ưu. Khoảng nồng độ làm việc của cả ba hợp chất phân tích từ 0,5 đến 5 ppm. Phương pháp này đã được ứng dụng để xác định hàm lượng niken, chì và kẽm trong mẫu nước máy với hiệu suất thu hồi (và độ lêch chuẩn) lần lượt là. 103,3 \% (3,0 \%), 74.,9 \% (11,5\%) và 104,6\% (4,6\%). 600 nm của 30 hỗn hợp chất chuẩn. Tất cả

Từ khoá: Bình phương tối thiểu từng phần, chì, niken, kẽm, trắc quang, đường chuẩn đa biến.

Trang 150 


\section{REFERENCES}

[1]. B. Zawisza, R. Sitko, E. Malicka, E. Talik, Graphene oxide as a solid sorbent for the preconcentration of cobalt, nickel, copper, zinc and lead prior to determination by energy-dispersive X-ray fluorescence spectrometry, Anal. Methods, 5, 6425-6430 (2013).

[2]. Y. Ni, L. Jin, Simultaneous polarographic chemometric determination of lead, copper, vanadium, cadmium and nickel, Chemometr. Intell. Lab., 45, 105-111 (1999).

[3]. S. Saracoglu, U. Divrikli, M. Soylak, L. Elci, Determination of copper, iron, lead, cadmium, cobalt and nickel by atomic absorption spectrometry in baking powder and baking soda samples after preconcentration and separation, J. Food. Drug. Anal., 10, 188-194 (2002).

[4]. J. Moss, C. Hardaway, J. Richert, J.
Sneddon, Determination of cadmium copper, iron, nickel, lead and zinc in crawfish [Procambrus clarkii] by inductively coupled plasma optical emission spectrometry: a study over the 2009 season in Southwest Louisiana, Microchem. J., 95, 5-10 (2010).

[5]. A. Niazi, Spectrophotometric Simultaneous determination of uranium and thorium using partial least squares regression and orthogonal signal correction, J. Braz. Soc. Mech. Sci., 17, 1020-1026 (2006).

[6]. L. Eriksson, E. Johansson, N. KettanehWold, J. Trygg, C. Wikstrom, S. Wold, Multi- and megavariate data analysis, $M K S$ Umetrics $A B$ (2006).

[7]. Guidelines for Dietary Supplements and Botanicals, AOAC Official Methods of Analysis (2013). 